\title{
UPAYA MENINGKATKAN KETERAMPILAN MENULIS \\ MELALUI MEDIA GAMBAR SERI PADA SISWA KELAS III SEMESTER II SDN 8 MONTONG BAAN TAHUN PELAJARAN 2014/2015
}

\author{
(THE EFFORTS TO IMPROVE STUDENTS' WRITING SKILL THROUGH \\ SERIAL PICTURES OF CLASS III, SEMESTER II SDN 8 MONTONG BAAN, \\ ACADEMIC YEAR OF 2014/2015)
}

\author{
Sahuruddin \\ SDN 8 Montong Baan \\ Montong Baan, Sikur, Lombok Timur \\ Pos-el: akmalwiya@gmail.com
}

Diterima: 21 Agustus 2017; Direvisi: 17 Oktober 2017; Disetujui: 14 November 2017

\begin{abstract}
The study aimed at finding out the improvement of students' writing skill in class III, Semester II SDN Montong Baan, academic year 2014/2015. The subject of the study is Students of class III, Semester II SDN Montong Baan, academic year 2014/2015 with a total of 26 students comprised of 12 males and 14 females. The study applies two cycles. Each cycle consists of four steps, namely are planning, executing, observing/evaluating, and reflecting. The method used is observation, questioner/test, and documentation. Observation conducted to observe the execution process being conducted. Questioner/test is used to find out the result of learning and achievement. Documentation is for supplement material for teaching and learning process. The result of the study shows that the achievement of Students in class III, Semester II SDN Montong Baan, academic year 2014/2015 in learning bahasa Indonesia on writing a simple essay based on the serial pictures using correct words and sentences choice considering spelling, capital letters, and punctuation before the execution phase is very low. It is showed by the achievement of 19\%. After the execution of using serial pictures, the student achievement is better. It is showed in cycle 1, the result increases to $57,69 \%$ with good category. In cycle 2, the result increases to $84,61 \%$ with very good category.
\end{abstract}

Keywords: writing skill, serial pictures

\begin{abstract}
Abstrak
Penelitian ini bertujuan untuk mengetahui peningkatan keterampilan menulis siswa kelas III, Semester II SDN 8 Montong Baan, Tahun Pelajaran 2014/2015. Subjek penelitian ini adalah siswa kelas III, semester 2 SDN 8 Montong Baan, Tahun Pelajaran 2014/2015 dengan jumlah siswa 26 orang yang terdiri atas12 siswa laki-laki dan 14 siswa perempuan. Prosedur pelaksanaan penelitian ini terdiri atas dua
\end{abstract}


siklus.Tiap siklus terdiri atas empat tahapan, yaitu perencanaan, pelaksanaan, pengamatan dan evaluasi, dan refleksi. Metode yang digunakan dalam penelitian ini adalah observasi, angket/tes, dan dokumentasi. Observasi digunakan untuk mengamati jalannya proses tindakan yang dilakukan. Angket/tes digunakan untuk mengetahui hasil belajar yang dicapai. Dokumentasi digunakan untuk bahan penunjang proses pembelajaran. Hasil penelitian ini menunjukkan bahwa hasil belajar bahasa Indonesia materi menulis karangan sederhana berdasarkan gambar seri menggunakan pilihan kata dan kalimat yang tepat dengan memperhatikan penggunaan ejaan, huruf kapital, dan tanda titik pada siswa kelas III semester 2 SDN 8 Montong Baan, Tahun Pelajaran 2014/2015 sebelum dilakukan tindakan sangat rendah. Hal ini dibuktikan dengan persentase keberhasilannya adalah $19 \%$. Setelah dilakukan tindakan penggunaan media gambar berseri, hasil belajar para siswa tergolong sangat baik. Hal ini terbukti dengan persentasi keberhasilan pada variabel hasil belajar siswa pada siklus 1 yaitu 57,69\% dengan kriteria baik dan siklus 2 adalah 84,61\% dengan kriteria sangat baik.

Kata Kunci: keterampilan menulis, gambar seri

\section{Pendahuluan}

Keterampilan menulis paragraf nonfiksi merupakan keterampilan berbahasa yang dirasakan paling sulit oleh sebagian besar siswa jika dibandingkan dengan keterampilan berbahasa lainnya, seperti membaca, menyimak, dan berbicara. Hal ini pula dirasakan oleh sebagian besar guru bahasa Indonesia di sekolah-sekolah dengan berpedoman pada tingkat antusiasme siswa dan kualitas tulisan yang dihasilkan siswa. Hal ini disebabkan keterampilan menulis merupakan keterampilan produktif yang harus membutuhkan keterampilan lain, seperti membaca dan penguasaan kosakata yang baik. Oleh karena itu, pembelajaran keterampilan menulis memerlukan teknik dan media yang tepat sehingga memudahkan siswa dalam belajar.

Salah satu media yang tepat dalam pembelajaran keterampilan menulis adalah media gambar berseri. Melalui gambar berseri, siswa akan terstimulan untuk memproduksi tulisan dengan panduan gambar yang mereka lihat. Hal ini terbukti pada hasil belajar menulis karangan narasi pada siswa kelas IV SDN Moahino. Berdasarkan hasil tes awal, siswa yang tuntas individu sejumlah 4 orang dengan ketuntasan klasikal sebanyak $20 \%$. Pada siklus I, siswa tuntas secara individu sebanyak 9 orang dengan ketuntasan klasikal 45\%. Kemudian pada siklus II, siswa yang tuntas secara individu sebanyak 17 orang dengan ketuntasan belajar klasikal $85 \%$. Berdasarkan hasil analisis data tersebut, dapat disimpulkan bahwa terjadi peningkatan sebanyak $40 \%$ dari siklus I ke siklus II (pembelajaran dengan menggunakan media gambar seri) dan meningkatkan 
minat murid dalam mengikuti pembelajaran khususnya di kelas IV SDN Moahino (Putra, 2017).

Keberhasilan dalam sebuah pembelajaran ditentukan oleh berbagai faktor, baik yang terkait langsung dengan proses pembelajaran tersebut maupun yang tidak berkaitan secara langsung. Faktor-faktor yang dimaksud antara lain: (1) kemampuan dan keterampilan guru dalam menjalankan tugasnya sebagai seorang pendidik dan pengajar; (2) penggunaan metode dan teknik mengajar yang tepat oleh seorang guru; (3) penggunaan media pembelajaran yang sesuai dengan setiap materi pada berbagai mata pelajaran; (4) kesiapan mental dan fisik siswa yang akan menerima pembelajaran; (5) ketersediaan sarana dan prasarana pembelajaran yang memadai yang dapat dimanfaatkan siswa dalam menerima pelajaran; dan (6) dukungan penuh, baik aspek materi maupun nonmateri dari semua pemangku kebijakan dalam dunia pendidikan.

Dalam Penelitian Tindakan Kelas ini, aspek yang akan dikaji adalah penggunaan media dalam peningkatan hasil belajar siswa. Penggunaan media pembelajaran selama ini diasumsikan oleh banyak guru adalah sesuatu yang mahal dan sulit dicari. Asumsi ini jelas tidak benar karena penggunaan pembelajaran menciptakan suasana belajar menyenangkan, efektif, dan efisien. Media tersebut dapat diperoleh dari berbagai sumber dan tidak harus mahal. Penggunaan media pembelajaran diutamakan sesuatu yang dekat dengan siswa sehingga pembelajaran yang bermakna dapat diperoleh siswa. Dengan demikian, hasil pembelajaran pun diharapkan dapat meningkat dengan penggunaan media tersebut.

Dalam lampiran Peraturan Menteri Pendidikan Nasional No. 23 Tahun 2006, tentang Standar Kompetensi Kelulusan (SKL) Kurikulum Tingkat Satuan Pendidikan (KTSP) Sekolah Dasar (SD) kelas III, terdapat Standar Kompetensi (SK) dan Kompetensi Dasar (KD). Salah satu Standar Kompetensi yang disebutkan dalam dokumen KTSP tersebut adalah (8. Mengungkapkan pikiran, perasaan, dan informasi dalam karangansederhana dan puisi). Standar Kompetensi ini kemudian diturunkan menjadi Kompetensi Dasar, yaitu (8.1 menulis karangan sederhana berdasarkan gambar seri, menggunakan pilihan kata dan kalimat yang tepat dengan memperhatikan penggunaan ejaan, huruf kapital, dan tanda titik).

SK dan KD tersebut mengharuskan siswa kelas III SD untuk mampu mengungkapkan pikiran, perasaan, dan informasi dalam bentuk tulisan sederhana 
berdasarkan gambar seri dengan memperhatikan pilihan kata dan kalimat yang tepat, penggunaan ejaan, huruf kapital, dan tanda titik. Namun, kenyataan di lapangan menunjukkan bahwa sebagian besar siswa belum mampu memahami materi tersebut. Hal ini dilihat dari hasil evaluasi 26 orang siswa yang terdiri atas laki-laki 12 orang dan perempuan 14 orang yang mendapat nilai $\geq 65$ sebanyak 5 orang dan $\leq 65$ sebanyak 21 orang dengan KKM 65. Artinya, dari 26 orang siswa, yang mengalami ketuntasan belajar baru mencapai 19\%, sedangkan target ketuntasan belajar adalah $75 \%$.

Berdasarkan temuan di lapangan tersebut, penulis berinisiatif menganalisis kembali penyebab rendahnya hasil belajar tersebut dengan memanfaatkan media belajar yang sesuai. Analisis mengenai rendahnya hasil belajar siswa kelas III Semester 2 di SDN 8 Montong Baan pada mata pelajaran bahasa Indonesia dilaksanakan melalui Penelitian Tindakan Kelas (PTK). PTK dibuat dengan judul "Upaya Meningkatkan Keterampilan Menulis Melalui Media Gambar Seri pada Siswa Kelas III Semester 2 di SDN 8 Montong Baan, Tahun Pelajaran 2014/2015". Dengan menerapkan media gambar seri, diharapkan keaktifan dan hasil belajar siswa SDN 8 Montong Baan Tahun Pelajaran 2014/2015 meningkat pada mata pelajaran bahasa Indonesia.

\section{Kerangka Teori}

\section{a. Pembelajaran Menulis di SD}

Gagne (1977) menjelaskan bahwa pembelajaran adalah seperangkat peristiwa-peristiwa eksternal yang dirancang untuk mendukung beberapa proses belajar yang bersifat internal. Lebih lanjut, Gagne (1985) mengemukakan teorinya lebih lengkap dengan mengatakan bahwa pembelajaran dimaksudkan untuk menghasilkan belajar, situasi eksternal harus dirancang sedemikian rupa untuk mengaktifkan, mendukung, dan mempertahankan proses internal yang terdapat dalam setiap peristiwa belajar. Penjelasan tersebut mengandung pengertian bahwa proses belajar merupakan salah satu aktivitas yang dilakukan dalam proses pembelajaran. Belajar itu sendiri diartikan sebagai suatu proses usaha yang dilakukan oleh seseorang untuk memperoleh suatu perubahan baru sebagai hasil pengalamannya sendiri dalam interaksinya dengan lingkungannya (Sobry, 2017). Perubahan yang dimaksud dalam hal ini adalah perubahan yang terjadi secara 
sengaja dan bertujuan untuk memperoleh sesuatu yang lebih baik dari sebelumnya, misalnya belajar membaca dan menulis.

Menulis adalah menurunkan atau melukiskan lambang-lambang grafik yang menggambarkan suatu bahasa yang dipahami seseorang sehingga orang lain dapat memahami lambang-lambang grafik tersebut yang di dalamnya mengandung pesan yang dibawa penulis (Sutari, 1997). Berdasarkan penjelasan pembelajaran dan menulis yang telah diutarakan pakar di atas, dapat ditarik simpulan bahwa pembelajaran menulis adalah suatu aktivitas yang dirangkai sehingga tercipta suasana yang memungkinkan seseorang untuk mengalami perubahan dalam hal kemampuan melukiskan lambang-lambang grafik sehingga orang lain dapat memahami lambang-lambang grafik tersebut sebagai sebuah pesan. Pembelajaran menulis ini dapat dilakukan pada berbagai jenjang pendidikan, misalnya SD, SMP, SMU, dan Perguruan Tinggi.

Peningkatan keterampilan menulis ini akan dapat dilihat berdasarkan rubrik penilaian, seperti potongan gambar disusun secara runtut dan logis, pemilihan kalimat utama sesuai dengan gambar, pengembangan kalimat utama menjadi kalimat logis dan sederhana, ketepatan penulisan ejaan dan tanda baca, kesesuaian judul dan isi, dan kerapihan tulisan.

Kegiatan menulis tidak dapat terlepas dari kegiatan bahasa lainnya, seperti kegiatan membaca, menyimak, dan berbicara. Untuk itu, dalam pelaksanaan pembelajaran, guru harus dapat memadukan keempat unsur kebahasaan tersebut sesuai dengan tujuan pembelajaran yang hendak dicapai. Pelaksanaan pembelajaran menulis di SD, terutama di kelas I dan III tidak dapat dipisahkan dengan pelajaran membaca permulaan, walaupun membaca dan menulis merupakan dua kemampuan yang berbeda. Menulis bersifat produktif, sedangkan membaca bersifat reseptif.

Pengembangan kemampuan menulis di SD banyak bergantung kepada kreativitas seorang guru. Oleh karena itu, guru harus membekali dirinya dengan kemampuan menulis. Guru juga dituntut mampu memilih metode yang sesuai sehingga dapat merangsang kreativitas siswa. Latihan yang intensif dan terarah akan dapat membimbing siswa memiliki kemampuan menulis sesuai dengan tujuan yang ingin dicapai. Dalam hal ini, setiap guru hendaknya menyadari bahwa 
pembelajaran menulis tidak ditekankan pada pengetahuan kebahasaan, tetapi bagaimana menerapkan pengetahuan tersebut.

Materi pembelajaran bahasa Indonesia dalam KTSP (2006) memuat beberapa standar kompetensi yang berisi pengembangan kemampuan menulis siswa, baik dalam segi kebahasaan maupun nonkebahasaan. Materi pembelajaran bahasa Indonesia SD memuat berbagai kompetensi dalam aspek menulis, seperti menulis tentang berbagai topik, pengumuman, pantun, dan surat. Dalam berbagai kegiatan menulis tersebut, siswa diharapkan nantinya dapat menulis dengan memperhatikan unsur-unsur kebahasaan dalam kaidah penulisan bahasa Indonesia yang baik dan benar, seperti penggunaan ejaan, huruf, dan tanda baca.

Berdasarkan isinya, jenis tulisan dibedakan menjadi lima, yaitu menulis diskripsi, narasi, argumentasi dan eksposisi, dan persuasi. Peneliti pada PTK ini memfokuskan penelitian pada penulisan karangan narasi berdasarkan gambar seri pada siswa kelas III SDN 8 Montong Baan, Lombok Timur.

\section{b. Manfaat Media}

Media adalah alat yang digunakan untuk menyalurkan pesan atau informasi dari pengirim kepada penerima pesan (Suparman dalam Sobry, 2017). Pakar lain yaitu Gearlach \& Ely (dalam Sobry, 2017) mendefinisikan bahwa media apabila dipahami secara garis besar adalah manusia, materi atau kejadian yang membangun suatu kondisi yang membuat siswa mampu memperoleh pengetahuan, keterampilan, atau sikap. Dari definisi media dari kedua pakar di atas, dapat tarik benang merah bahwa media adalah sarana yang digunakan dalam pembelajaran yang memungkinkan siswa dapat mengikuti proses belajar dengan lebih mudah. Media pembelajaran dapat berupa media cetak, alat peraga, gambar, dan lain-lain. Dewasa ini, semakin banyak guru yang mengunakan media sebagai pendukung proses pengajaran. Hal ini dipengaruhi oleh semakin tingginya nilai kesadaran para guru tentang betapa besarnya manfaat dan peranan media dalam proses belajar mengajar. Salah satu media yang dapat digunakan dalam pembelajaran menulis adalah media gambar seri sebagaimana yang telah diterapkan pada kelas IV SDN Moahino (Putra, 2017).

Manfaat media dan teknologi dilihat dari beberapa segi adalah sebagai berikut: 
1) Ditinjau dari segi isi (content) ide atau pesan (massage) yang diajarkan, kegunaan media adalah menyajikan hal-hal secara biasa tidak dapat disajikan karena berbagi sebab, misalnya terlalu luas, lebar, sempit, kecil, berbahaya, kompleks, sudah lampau, atau belum terjadi.

2) Ditinjau dari jumlah penerimaanya (siswa, publik, dan sebagainya), media bermanfaat untuk menghubungi orang banyak, jauh lebih banyak daripada disebarkan tanpa media.

3) Unsur waktu melalui media banyak disebarkan dengan cepat beberapa saat setelah terjadinya sutu peristwa.

4) Hubungan unsur dengan unsur psikologis dari penerima. Media yang baik dapat menambah kesan dramatik atau realitik sehinga orang yang menerimanya lebih menaruh perhatian, lebih percaya, atau lebih tergentar emosinya (Djamarah dan Zain 2002:152)

Dalam pengajaran menulis narasi, pengunaan media akan membantu siswa dalam meningkatkan ide-ide mereka ke dalam tulisan.

Media gambar sebagai bahan pembelajaran memiliki beragam bentuk, yaitu: bagan, diagram, grafik, poster, media komik, dll. Setiap bentuk media gambar ini dapat digunakan pada berbagai materi yang relevan dengan bentuk masingmasing. Secara umum, media gambar dengan segala bentuknya memiliki keunggulan dan kelemahan. Keunggulan media gambar adalah (a) dapat menerjemahkan ide-ide abstrak ke dalam bentuk yang lebih nyata sehingga memudahkan siswa dalam merangkai sebuah cerita berdasarkan gambar yang mereka lihat; (b) sumber media gambar dapat diperoleh dengan mudah karena media gambar banyak tersedia dalam buku-buku, majalah, koran, katalog, atau kalender. Hal ini sangat memungkinkan bagi guru untuk dapat memanfaatkan sumber-sumber tersebut; (c) media gambar dengan semua bentuknya dapat dikatakan cukup praktis dan sangat mudah dipakai karena tidak membutuhkan peralatan. Dalam hal ini, guru hanya dituntut bagaimana mengkreasikan gambar sehingga lebih rapi dan menarik sehingga meningkatkan antusiasme siswa dalam belajar; (d) media gambar tergolong tidak mahal sehingga tidak membutuhkan biaya banyak dalam menyediakannya; dan (e) media gambar dapat digunakan pada semua jenjang pendidikan danpada berbagai bidang studi. 
Selain memiliki keunggulan, media gambar juga memiliki kelemahan, yaitu: (a) media gambar terkadang terlalu kecil untuk dipertunjukan di kelas yang besar. Untuk mengatasi hal ini, guru dapat memanfaatkan media belajar alternatif, misalnya LCD untuk menampilkan gambar yang lebih besar. Namun, hal ini juga sering terkendala teknis dan kompetensi guru dalam pemanfaatan media belajar berbasis teknologi; (b) media gambar mati adalah gambar dua dimensi. Untuk menujukkan dimensi yang ketiga (ke dalam benda), harus digunakan satu seri gambar dari objek yang sama, tetapi dari sisi yang berbeda; (c) media gambar tidak dapat menujukkan gerak. Hal ini terkadang membuat siswa tidak tertarik, terlebih siswa yang terbiasa dengan gambar-gambar bergerak yang disediakan di rumah; dan (d) anak tidak selalu "membaca" (menginterprestasikan) gambar (Hastuti 1996:178).

\section{Metode Penelitian}

\subsection{Setting Penelitian}

Subjek dalam penelitian ini adalah siswa kelas III Semester 2 di SDN 8 Montong Baan dengan jumlah siswa adalah 26 orang yang terdiri atas laki-laki 12 orang dan perempuan 14 orang. Penelitian ini dilaksanakan pada bulan Januari-- Maret 2015.

\subsection{Prosedur Siklus Penelitian}

Penelitian ini adalah Penelitian Tindakan Kelas (PTK) atau Classroom Action Research dengan tujuan memperbaiki mutu praktik pembelajaran di kelas. PTK ini dilakukan sebanyak 2 siklus. Tiap siklus terdiri atas empat tahapan, yaitu perencanan tindakan (planning), pelaksanaan tindakan (action), observasi dan pengenalan proses dan hasil tindakan (observation and evaluation), dan refleksi (reflection). Keempat tahapan tersebut merupakan satu siklus yang selalu berulang. Siklus pertama dilaksanakan sebanyak 2 kali pertemuan, yaitu pada tanggal 10 dan 13 Februari 2015. Begitu pula siklus kedua sebanyak 2 kali pertemuan, yaitu tanggal 3 dan 6 Maret 2015. Siklus dalam penelitian ini akan berakhir apabila hasil belajar siswa secara individu dapat memperoleh nilai minimal 65 dengan ketuntasan belajar $75 \%$. 
Penggunaan media gambar seri dilakukan pada siklus II untuk mengetahui efektivitas pembelajaran dengan menggunakan media gambar seri. Adapun siklus I tidak menggunakan media gambar seri sehingga bisa dibandingkan hasil pembelajaran yang menggunakan media gambar dan yang tidak menggunakan media gambar. Model pelaksanaan pembelajaran dijelaskan pada bagian pembahasan subbab Pelaksanaan Siklus II di bawah.

\subsection{Pengumpulan Data}

\subsubsection{Teknik Tes}

Tes adalah seperangkat tugas yang harus dikerjakan atau sejumlah pertanyaan yang harus dijawab oleh peserta didik untuk mengukur tingkat pemahaman dan penguasaannya terhadap cakupan materi yang dipersyaratkan dan sesuai dengan tujuan pengajaran tertentu (Poerwanti, 2008:1--5). Tes dalam penelitian ini digunakan untuk mengukur kemampuan siswa dalam menulis karangan sederhana berupa lembar kerja siswa.

\subsubsection{Teknik Nontes}

a. Observasi

Observasi adalah teknik penilaian yang dilakukan oleh pendidik dengan melakukan mengamatan langsung dengan menggunakan indera (Mudjito, 2009:14). Observasi digunakan untuk mengamati aktivitas siswa dan keterampilan guru dalam pembelajaran menulis karangan sederhana bahasa Indonesia dengan media gambar berseri. Dalam observasi ini, digunakan lembar instrumen keterampilan guru dan pengamatan aktivitas siswa saat pembelajaran berlangsung.

b. Dokumentasi

Dokumentasi adalah himpunan pertanyaan yang harus dijawab, pertanyaanpertanyaan yang harus dipilih atau ditanggapi atau tugas-tugas yang harus dilakukan oleh peserta tes dengan tujuan untuk mengukur suatu aspek tertentu dari peserta tes (Poerwanti, 2008:3--4). Dokumentasi digunakan untuk memperoleh daftar nama siswa yang akan menjadi subjek penelitian dan memperoleh data nilai awal siswa sebelum dilakukan PTK. 


\subsection{Analisis Data}

Penelitian ini merupakan penelitian tindakan yang termasuk dalam penelitian kualitatif walaupun data yang dikumpulkan bisa saja bersifat kuantitatif. Hal ini disebabkan penelitian ini berbeda dengan penelitian formal yang bertujuan untuk menguji hipotesis dan membangun teori yang bersifat umum (general). Penelitian tindakan ini lebih bertujuan untuk memperbaiki kinerja, sifatnya kontekstual, dan hasilnya tidak untuk digeneralisasi. Dengan demikian, penelitian ini bersifat deskriptif yang berarti hanya memaparkan data yang diperoleh melalui lembar kerja, observasi, dan tes hasil belajar setiap siklus. Data yang diperoleh melalui observasi dan tes hasil belajar dianalisis dengan menggunakan statistik deskriptif, yaitu statistik yang berfungsi untuk menggambarkan tentang suatu keadaan.

\section{Pembahasan}

\subsection{Hasil Penelitian}

\subsubsection{Pelaksanaan Siklus I}

Pelaksanaan siklus I dilaksanakan di SDN 8 Montong Baan, pada hari Selasa, tanggal 10 dan 13 Februari 2015, di kelas III semester 2, mata pelajaran bahasa Indonesia dengan alokasi waktu 2 x 35 menit. Adapun pelaksanaan siklus I adalah sebagai berikut.

1) Kegiatan awal

Pada kegiatan awal ini, guru menginformasikan materi yang akan dibahas melalui peta konsep beserta tujuan pembelajaran. Dilanjutkan dengan memberi apersepsi, yaitu dengan memberi pertanyaan yang berkaitan dengan materi pembelajaran, kemudian guru menginformasikan cara belajar dengan menggunakan media gambar berseri.

2) Kegiatan inti

Kegiatan inti meliputi eksplorasi, elaborasi, dan konfirmasi. Dalam kegiatan eksplorasi, guru membacakan cerita mengenai kesehatan manusia dengan menggunakan media gambar berseri dan para siswa mendengarkan penjelasan dari 
guru. Dalam pembelajaran, nampak siswa memperhatikan dengan seksama walaupun ada beberapa siswa nampak sedikit tidak semangat mengikuti pembelajaran. Dalam hal ini, guru memberi teguran dan peringatan kepada siswa tersebut agar bersungguh-sungguh dalam mengikuti pelajaran dengan menegur dan memberikan beberapa pertanyaan tentang materi yang sedang diajarkan. Tujuannya agar perhatian siswa tertuju pada materi pembelajaran kembali. Sesekali siswa memberikan tanggapan mengenai materi yang belum mereka pahami.

Pada kegiatan elaborasi, guru membagikan siswa rangkaian gambar berseri. Hal ini dimaksudkan agar siswa berimajinasi dan mampu menuliskan kalimat sederhana pada masing-masing gambar sebagai pikiran pokok. Setelah itu, siswa secara mandiri mengembangkan pikiran pokok menjadi beberapa kalimat sehingga terbentuk sebuah karangan yang runtut. Kemudian, siswa secara individu memberikan pendapat dan memilih karangan terbaik dari beberapa siswa untuk dibaca di depan kelas sesuai lafal dan intonasi. Guru bersama siswa memberikan tanggapan. Selanjutnya guru melaksanakan kegiatan konfirmasi dan guru memberikan tanggapan dari hasil kerja siswa. Siswa melakukan refleksi untuk memperoleh pengalaman belajar dan guru memberi motivasi agar siswa lebih berpartisipasi aktif.

Selama proses pembelajaran, guru berkeliling kelas untuk mengontrol dan memonitoring proses belajar. Beberapa siswa tampak ramai dalam mengerjakan karangan sendiri. Melihat hal ini, guru menjelaskan agar siswa tenang dalam berimajinasi sesuai dengan gambar yang disediakan. Guru memberi motivasi bahwa belajar dengan tenang dapat memudahkan para siswa untuk berimajinasi.

\section{3) Kegiatan akhir}

Pada kegiatan ini, guru memberikan umpan balik kepada siswa dengan melontarkan beberapa pertanyaan dan memberi masalah-masalah yang bisa dipecahkan oleh siswa. Selanjutnya guru bersama siswa menyimpulkan materi dan guru memberikan tindak lanjut dengan merencanakan remidial dan pengayaan serta menyampaikan informasi materi pelajaran pada pertemuan selanjutnya. 
Keterampilan menulis karangan sederhana berbahasa Indonesia dengan media gambar berseri pada siswa kelas III SDN 8 Montong Baan pada siklus I belum menunjukkan hasil yang maksimal. Hasil observasi pada keterampilan menulis karangan sederhana berbahasa Indonesia dengan media gambar berseri dapat dilihat pada tabel di bawah ini.

\section{Tabel 1}

\section{Skor Keterampilan Siswa Menulis Karangan Sederhana} dengan Media Gambar Berseri Siklus I

\begin{tabular}{|c|c|c|c|c|c|c|c|}
\hline \multirow[t]{2}{*}{ No. } & \multirow[t]{2}{*}{ Aspek } & \multicolumn{4}{|c|}{$\begin{array}{l}\text { Perolehan } \\
\text { Skor }\end{array}$} & \multirow[t]{2}{*}{ Jumlah } & \multirow{2}{*}{$\begin{array}{c}\text { Rata- } \\
\text { rata }\end{array}$} \\
\hline & & 1 & 2 & 3 & 4 & & \\
\hline 1 & $\begin{array}{l}\text { Potongan gambar disusun secara runtut } \\
\text { dan logis }\end{array}$ & 4 & 4 & 15 & 3 & 69 & 2,6 \\
\hline 2 & $\begin{array}{l}\text { Pemilihan kalimat utama sesuai dengan } \\
\text { gambar }\end{array}$ & 2 & 12 & 11 & 1 & 63 & 2,4 \\
\hline 3 & $\begin{array}{l}\text { Pengembangan kalimat utama menjadi } \\
\text { kalimat logis dan sederhana }\end{array}$ & 6 & 7 & 12 & 1 & 48 & 1,8 \\
\hline 4 & Ketepatan penulisan ejaan dan tanda baca & 3 & 3 & 13 & 7 & 76 & 2,9 \\
\hline 5 & Kesesuaian judul dan isi & 4 & 5 & 7 & 10 & 75 & 2,9 \\
\hline 6 & Kerapihan tulisan & 3 & 4 & 12 & 7 & 75 & 2,9 \\
\hline \multicolumn{6}{|c|}{ Jumlah } & \multicolumn{2}{|c|}{406} \\
\hline \multicolumn{6}{|c|}{ Rata-rata } & \multicolumn{2}{|c|}{15,5} \\
\hline
\end{tabular}

Berdasarkan tabel di atas, tingkat keterampilan siswa menulis karangan sederhana pada siklus I adalah sebagai berikut.

1) Jumlah skor yang didapat pada aspek potongan gambar tersusun secara urut dan logis adalah 69 dengan rata-rata skor 2,6.

2) Jumlah skor yang didapat pada aspek pemilihan kalimat utama sesuai dengan gambar adalah 63 dengan rata-rata skor 2,4.

3) Jumlah skor yang didapat pada aspek Pengembangan kalimat utama menjadi paragraf logis dan sederhana adalah 48 dengan rata-rata skor 1,8.

4) Jumlah skor yang didapat pada aspek ketepatan penulisan ejaan dan tanda baca adalah 76 dengan rata-rata skor 2,9.

5) Jumlah skor yang didapat pada aspek kesesuaian judul dan isi adalah 75 dengan rata-rata skor 2,9 . 
6) Jumlah skor yang didapat pada aspek kerapian tulisan adalah 75 dengan ratarata skor 2,9.

7) Jumlah skor yang diperoleh secara keseluruhan untuk semua indikator pada siklus I adalah 406 dengan rata-rata skor 15,5.

Hasil belajar siswa menulis karangan sederhana berbahasa Indonesia dengan media gambar berseri adalah sebagai berikut.

\section{Tabel 2}

\section{Hasil Belajar Siswa Siklus I}

\begin{tabular}{|c|c|c|c|c|}
\hline Interval Nilai & Frekuensi & Frekuensi Relatif & KKM & Kualifikasi \\
\hline $80--100$ & 3 & $11 \%$ & \multirow{7}{*}{65} & Tuntas \\
\hline $65--79$ & 12 & $46 \%$ & & Tuntas \\
\hline $56-64$ & 5 & $19 \%$ & & Belum tuntas \\
\hline $40-55$ & 6 & $23 \%$ & & Belum tuntas \\
\hline Jumlah & 26 & & & \\
\hline Siswa tuntas & 15 & $57 \%$ & & \\
\hline $\begin{array}{l}\text { Siswa belum } \\
\text { tuntas }\end{array}$ & 11 & $43 \%$ & & \\
\hline
\end{tabular}

Berdasarkan analisis hasil belajar pada siklus I, ketuntasan belajar klasikal baru dicapai oleh 15 orang siswa atau sebesar $57 \%$ dan ketidaktuntasan belajar sebesar 43\%. Hasil tersebut dapat disajikan dalam diagram sebagai berikut.

\section{Diagram 1}

\section{Diagram ketuntasan belajar siswa secara klasikal Siklus I}

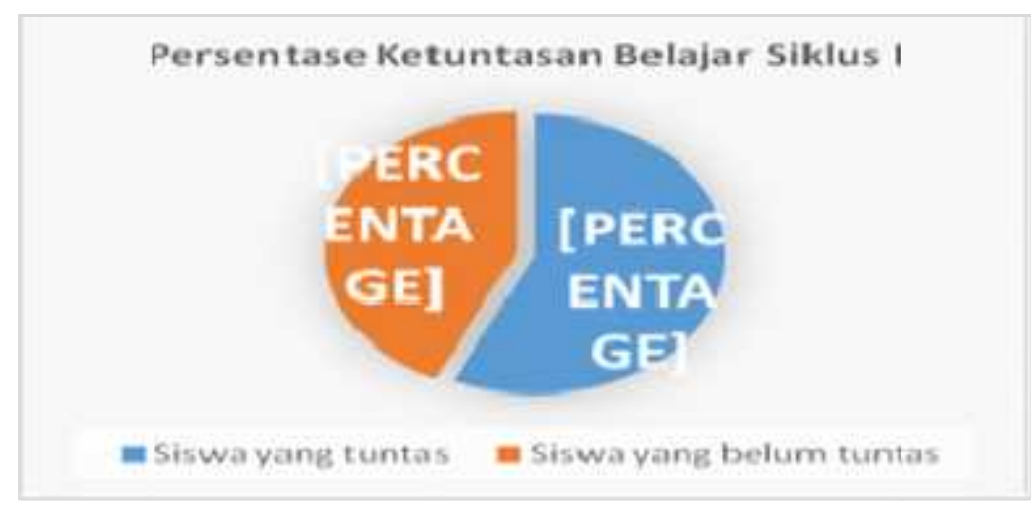

Hasil belajar siklus I di atas menunjukkan bahwa target ketuntasan belajar masih jauh dari harapan. Ketidaktuntasan belajar pada siklus I ini disebabkan penggunaan media belajar yang tidak menarik dan tidak relevan dengan materi yang diajarkan. Hal ini menyebabkan motivasi belajar siswa yang rendah sehingga hasil belajar pun tidak maksimal. Dengan demikian, penggunaan media belajar 
yang tepat perlu diperhatikan sehingga motivasi dan hasil belajar siswa dapat dicapai sebagaimana yang telah ditargetkan. Hal inilah yang disebut oleh Sobry (2017) bahwa ketepatan penggunaan media berkaitan dengan proses dan hasil yang dicapai dalam pembelajaran. Lebih lanjut Sobry (2017) menjelaskan bahwa ketepatan itu berkaitan dengan pertanyaan, apakah dalam penggunaan media tersebut informasi pengajaran dapat diserap oleh anak didik secara optimal.

Mencermati data hasil belajar siklus I di atas, dapat disimpulkan bahwa pembelajaran perlu dilanjutkan ke tahapan berikutnya, yaitu siklus II. Adapun pelaksanaan siklus II dijelaskan pada uraian di bawah ini.

\subsubsection{Pelaksanaan Siklus II}

Siklus II dilaksanakan pada tanggal 3 dan 6 Maret 2015. Materi pada siklus II adalah menulis karangan sederhana berbahasa Indonesia dengan media gambar berseri, tema kesehatan. Alokasi waktu pada siklus II adalah 4 jam pelajaran ( $4 \mathrm{x}$ 35 menit). Pembelajaran diikuti oleh siswa kelas III SDN 8 Montong Baan sejumlah 26 siswa.

Uraian kegiatan pembelajaran pada siklus II diuraikan sebagai berikut.

\section{1) Kegiatan Awal}

Pada kegiatan awal ini, guru menginformasikan materi yang akan dibahas melalui peta konsep beserta tujuan pembelajaran. Dilanjutkan dengan memberi apersepsi, yaitu dengan memberi pertanyaan yang berkaitan dengan materi pembelajaran, kemudian guru menginformasikan cara belajar dengan menggunakan media gambar berseri.

\section{2) Kegiatan Inti}

Kegiatan inti meliputi eksplorasi, elaborasi, dan konfirmasi. Dalam kegiatan eksplorasi, salah satu siswa membacakan cerita mengenai kesehatan. Bersamaan dengan itu, guru membagikan rangkaian gambar berseri sesuai dengan cerita yang dibacakan agar siswa mampu berimajinasi secara konkret. Siswa mendengarkan penjelasan dari guru. Dalam pembelajaran, nampak siswa memperhatikan dengan seksama walaupun ada beberapa siswa nampak sedikit tidak semangat mengikuti 
pembelajaran. Dalam hal ini, guru memberi teguran dan peringatan kepada siswa tersebut agar bersungguh-sungguh dalam mengikuti pelajaran dengan menegur dan memberikan beberapa pertanyaan tentang materi yang sedang diajarkan. Tujuannya agar perhatian siswa tertuju pada materi pembelajaran kembali. Sesekali siswa memberikan tanggapan mengenai materi yang belum mereka pahami.

Pada kegiatan elaborasi, guru membagikan siswa potongan gambar berseri dan mengurutkan gambar. Hal ini dimaksudkan agar siswa berimajinasi dan mampu menuliskan kalimat sederhana pada masing-masing gambar sebagai pikiran pokok. Setelah itu, siswa secara mandiri mengembangkan pikiran pokok menjadi beberapa kalimat sehingga terbentuk sebuah karangan yang runtut. Kemudian, siswa memberikan pendapat dan memilih karangan terbaik dari beberapa siswa untuk dibacakan di depan kelas sesuai lafal dan intonasi. Guru bersama siswa memberikan tanggapan. Selanjutnya, guru melaksanakan kegiatan konfirmasi dan guru memberikan tanggapan dari hasil kerja siswa. Siswa melakukan refleksi untuk memperoleh pengalaman belajar dan guru memberi motivasi agar siswa lebih berpartisipasi aktif.

Selama proses pembelajaran, guru berkeliling kelas untuk mengontrol dan memonitoring proses belajar. Dalam kegitan itu, masih ada yang ramai dalam mengerjakan tugas. Melihat hal ini, guru menjelaskan agar siswa tenang menyelesaikan tugas dan memberikan motivasi bahwa belajar dalam situasi tenang akan memudahkan para siswa untuk berimajinasi.

\section{3) Kegiatan Akhir}

Pada kegiatan ini, guru memberikan umpan balik kepada siswa dengan melontarkan beberapa pertanyaan dan memberi masalah-masalah yang bisa dipecahkan oleh siswa. Selanjutnya, guru bersama siswa menyimpulkan materi dan guru memberikan tindak lanjut dengan merencanakan remidial dan pengayaan serta menyampaikan informasi materi pelajaran pada pertemuan selanjutnya.

Keterampilan menulis karangan sederhana berbahasa Indonesia dengan media gambar berseri pada siswa kelas III SDN 8 Montong Baan pada siklus II 
sudah memenuhi indikator keberhasilan. Hasil observasi pada keterampilan menulis karangan sederhana berbahasa Indonesia dengan media gambar berseri dapat dilihat pada tabel di bawah ini

Tabel 3

Skor Keterampilan Siswa Menulis Karangan Sederhana dengan Media gambar berseri Siklus II

\begin{tabular}{|c|c|c|c|c|c|c|c|}
\hline \multirow{2}{*}{ No } & \multirow{2}{*}{ Aspek } & \multicolumn{4}{|c|}{ Perolehan Skor } & \multirow{2}{*}{ Jumlah } & \multirow{2}{*}{$\begin{array}{l}\text { Rata- } \\
\text { rata }\end{array}$} \\
\hline & & 1 & 2 & 3 & 4 & & \\
\hline 1 & $\begin{array}{l}\text { Potongan gambar disusun secara runtut } \\
\text { dan logis }\end{array}$ & 4 & 2 & 9 & 9 & 71 & 3,0 \\
\hline 2 & $\begin{array}{l}\text { Pemilihan kalimat utama sesuai dengan } \\
\text { gambar }\end{array}$ & 2 & 4 & 5 & 15 & 83 & 3,4 \\
\hline 3 & $\begin{array}{l}\text { Pengembangan kalimat utama menjadi } \\
\text { kalimat logis dan sederhana }\end{array}$ & 1 & 4 & 10 & 11 & 76 & 3,2 \\
\hline 4 & Ketepatan penulisan ejaan dan tanda baca & 1 & 3 & 11 & 11 & 76 & 3,2 \\
\hline 5 & Kesesuaian judul dan isi & 1 & 1 & 5 & 19 & 91 & 3,1 \\
\hline 6 & Kerapihan tulisan & 1 & 2 & 9 & 14 & 82 & 3,4 \\
\hline & Jumlah & & & & & 47 & \\
\hline & Rata-rata & & & & & 19 & \\
\hline & Kategori & & & & & Tun & \\
\hline
\end{tabular}

Berdasarkan tabel di atas, hasil belajar siswa dalam menulis karangan sederhana berbahasa Indonesia dengan media gambar berseri pada siklus II dapat dirincikan sebagai berikut.

1) Jumlah skor yang didapat pada aspek potongan gambar tersusun secara urut dan logis adalah 71 dengan rata-rata skor 3,0.

2) Jumlah skor yang didapat pada aspek pemilihan kalimat utama sesuai dengan gambar adalah 83 dengan rata-rata skor 3,4.

3) Jumlah skor yang didapat pada aspek Pengembangan kalimat utama menjadi paragraf logis dan sederhana adalah 76 dengan rata-rata skor 3,2.

4) Jumlah skor yang didapat pada aspek ketepatan penulisan ejaan dan tanda baca adalah 76 dengan rata-rata skor 3,2.

5) Jumlah skor yang didapat pada aspek kesesuaian judul dan isi adalah 91 dengan rata-rata skor 3,1 .

6) Jumlah skor yang didapat pada aspek kerapihan tulisan adalah 82 dengan ratarata skor 3,4 . 
7) Jumlah skor yang diperoleh secara keseluruhan untuk semua indikator pada siklus II adalah 478 dengan rata-rata skor 19,9 termasuk kualifikasi tuntas.

Hasil observasi pada keterampilan menulis karangan sederhana berbahasa Indonesia dengan media gambar berseri dapat dilihat pada tabel di bawah ini.

\section{Tabel 4}

\section{Hasil Belajar Siswa Siklus II}

\begin{tabular}{|c|c|c|c|c|}
\hline Interval Nilai & Frekuensi & Frekuensi Relatif & KKM & Kualifikasi \\
\hline $80--100$ & 16 & $61 \%$ & \multirow{7}{*}{65} & Tuntas \\
\hline $65--79$ & 6 & $23 \%$ & & Tuntas \\
\hline $56-64$ & 2 & $8 \%$ & & Belum tuntas \\
\hline $40-55$ & 2 & $8 \%$ & & Belum tuntas \\
\hline Jumlah & 26 & & & \\
\hline Siswa tuntas & 22 & $84 \%$ & & \\
\hline $\begin{array}{l}\text { Siswa belum } \\
\text { tuntas }\end{array}$ & 4 & $16 \%$ & & \\
\hline
\end{tabular}

Berdasarkan analisis hasil belajar pada siklus II, ketuntasan belajar klasikal sebesar $84 \%$ dan ketidaktuntasan belajar sebesar $16 \%$. Hasil itu dapat disajikan dalam diagram sebagai berikut.

\section{Diagram 2}

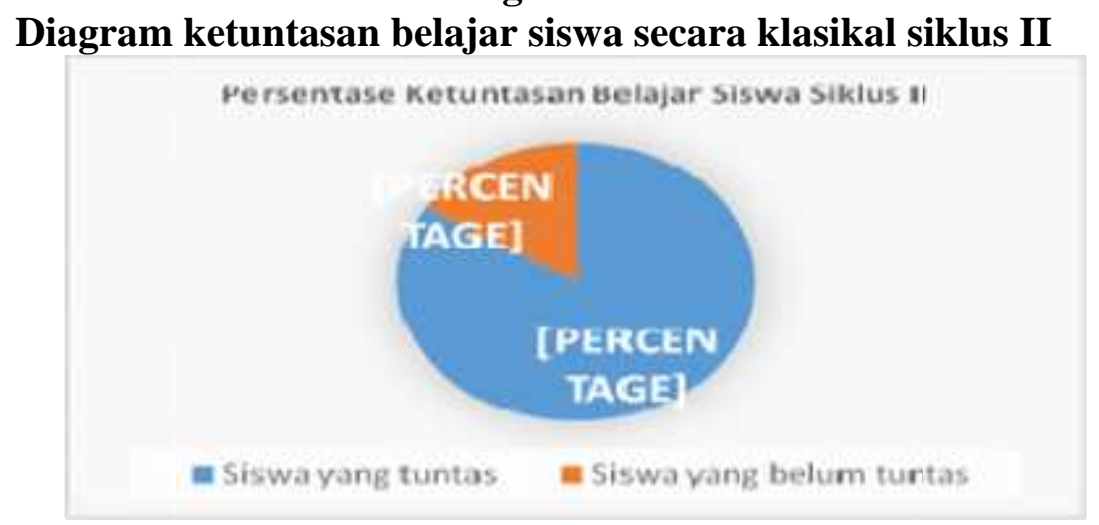

Dengan demikian, pada siklus II, hasil belajar siswa sudah mencapai indikator yang diharapkan dari tabel dan diagram tersebut. Data melalui tes tertulis sudah menunjukkan adanya peningkatan dan memenuhi indikator dari hasil menulis karangan sederhana berbahasa Indonesia dengan media gambar berseri pada siswa kelas III. 


\section{Penutup}

Hasil belajar bahasa Indonesia, materi menulis karangan sederhana, berdasarkan gambar seri dengan menggunakan pilihan kata dan kalimat yang tepat dengan memperhatikan penggunaan ejaan, huruf kapital, dan tanda titik pada siswa kelas III semester 2 SDN 8 Montong Baan Tahun Pelajaran 2014/2015 sebelum dilakukan tindakan sangat rendah, yaitu dari 26 orang siswa yang mendapat nilai $\geq 65$ adalah 5 orang dan $\leq 65$ yaitu 21 orang dengan KKM 65. Artinya, dari 26 orang siswa yang mengalami ketuntasan belajar baru mencapai 19\%, sedangkan target ketuntasan belajar adalah $75 \%$. Namun, setelah dilakukan tindakan yaitu pembelajran dengan menggunakan gambar berseri, peningkatan hasil belajar siswa meningkat signifikan. Setelah dilakukan tindakan penggunaan media gambar berseri, hasil belajar tergolong sangat baik. Hal ini terbukti dengan persentase keberhasilan pada variabel hasil belajar siswa pada siklus 1 yaitu sebesar 57,69\% dengan kriteria baik dan pada siklus 2 sebesar $84,61 \%$ dengan kriteria sangat baik.

\section{Daftar Pustaka}

Ahkadiah, S., dkk. (2003). Pembinaan Kemampuan Menulis Bahasa Indonesia. Jakarta: Erlangga.

Angkoso, Robertes dan Kosasih, A. (2007). Optimalisasi Media Pembelajaran. Jakarta: Grasindo

Djamarah. (2002). Prestasi Belajar dan Kompetensi Guru. Surabaya: Usaha Nasional.

Djamarah, Syaiful Bahri dan Zain, Aswan. (2010). Strategi Belajar Mengajar. Jakarta: Rineka Cipta.

Fathurrohman P. dan M. Sobry. (2017). Strategi Belajar Mengajar Melalui Penanaman Konsep Umum dan Konsep Islami. Bandung: Refika Aditama.

Hastuti, Sri. (1996). Strategi Belajar Mengajar Bahasa Indonesia. Jakarta: Depdikbud

Keraf, Gorys. (1983). Argumentasi dan Narasi. Jakarta: Gramedia.

Keraf, Gorys. (1995). Eksposisi. Jakarta: Gramedia.

Nursisto. (1999). Penuntun Mengarang. Yogyakarta: Adicita.

Parera, Jos Daniel. (1993). Menulis Tertib dan Sistematik. Jakarta: Erlangga. 
Sujanto. (1988). "Keterampilan Menulis Karangan Narasi dengan Teknik Modeling pada Siswa Kelas 11 D SLTP Sukorejo Kendal 2003/2004”. Semarang.

http://www.sekolahdasar.net/2011/11/pembelajaran-menulis-di-sd.htmldiakses tanggal 15 Oktober 2016 pukul 17.00 


\title{
HARMONI BAHASA DARI PERSPEKTIF PENERJEMAHAN DALAM KASUS PEMADANAN ISTILAH TEKNIS \\ (A LANGUAGE HARMONY FROM THE TRANSLATION PERSPECTIVE IN THE EQUIVALENTOF TECHNICAL TERMS)
}

\author{
Muhamad Nur \\ Sekolah Tinggi Manajemen Informatika dan Komputer (STMIK) Bumigora \\ Jl. Ismail Marzuki_Mataram, NTB, Indonesia \\ Pos-el: insabil@gmail.com
}

Diterima: 27 Februari; Direvisi: 27 November 2017; Disetujui: 28 November 2017

\begin{abstract}
An importantpillar in the science system is that the term must have the same meaning for all users to achieve the best result of information exchange. Thus, through a general consensus of meaning, name and the specific term for consistently use will result in specific lexicon uniformity which contain the standard of concept, term and definition. Thearticle was as approach result in the translation related to the terminology specifically of technical terms. The approaches presented here wereas an alternative way referring to the concept equality principles between the donor and recipient languages. The data of article were taken through the online of internet access for journal, article and other references specifically presented in the English that studies about the terminology and other linguistic aspects textually oriented to the field of translation. Theresult of article showed thatthe interaction form among different languages in the translation field, specifically related to the technical terms could be conducted through the adaptation approach of linguistic aspects or linguistic rules of the donor language, according to the aspects or linguistic rules of the recipient languages. In one hand, this is conducted as an effort to strengthen the conceptual meaning owned by the donor languages, and in the other hand it is an effort of adapting the linguistic aspects or rules according to the recipient languages. Throughthe approach therefore, a language harmony could be constructed for the speaker or language users among the nation community itself.
\end{abstract}

Keywords: language harmony, translation, equivalent, technical terms

\begin{abstract}
Abstrak
Istilah merupakan sendi penting di dalam sistem ilmu pengetahuan, harus mempunyai makna yang sama bagi semua orang yang menggunakannya, agar pertukaran informasi memperoleh hasil yang baik, maka melalui kesepakatan umum tentang makna, nama dan istilah khusus serta
\end{abstract}

